\title{
R. ERVIN TAYLOR (1938-2019): IN MEMORIAM
}

\section{John Southon* (1)}

Keck AMS laboratory, Earth System Science Dept, B321 Croul Hall, University of California, Irvine, CA 92697-3100, USA

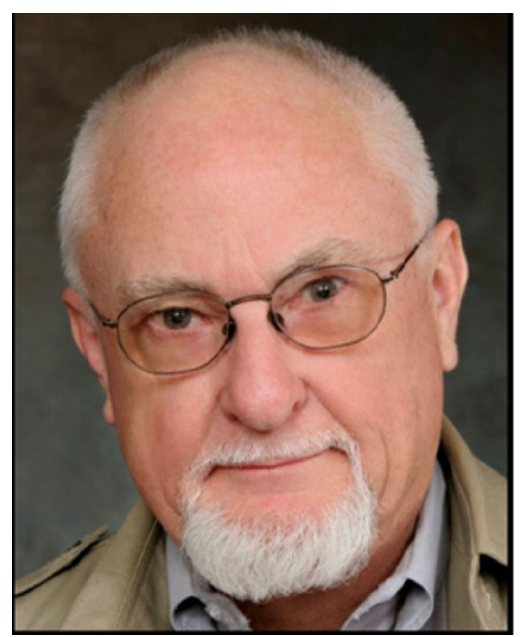

Erv Taylor (1938-2019)

(Photo courtesy of Adventist Today

Foundation.)

In 1959, the year before Willard Libby received the Nobel Prize for the development of radiocarbon dating, he left the US Atomic Energy Authority and took up a professorship at University of California Los Angeles (UCLA) where he set up a new radiocarbon laboratory. Erv Taylor, then a graduate student pursuing a $\mathrm{PhD}$ in the UCLA Anthropology Department, entered the field of radiocarbon studies when he was hired as a research assistant in the Libby lab in the mid-1960s. He was active in the field for over 50 years, and I was privileged to work with him first at the Lawrence Livermore National Lab in the 1990s and then at University of California Irvine from 2001.

After completing his doctorate in 1969, Erv moved to the Anthropology Department at University of California Riverside where he rose to the rank of full professor, was Head of Department from 1993 to 2000, and put his UCLA training to good use in setting up his own gas counting ${ }^{14} \mathrm{C}$ laboratory which operated successfully for 3 decades. In addition to his many published papers, he was author of Radiocarbon Dating: an Archaeological Perspective (Academic Press 1987) and co-editor of Radiocarbon After Four Decades: an Interdisciplinary Perspective (Springer-Verlag 1992): both are major reference works in the field. In 2003 he closed down the UCR counting laboratory and retired from UC Riverside, taking up dual positions as Visiting Fellow at UCLA's Cotsen Institute of Archaeology and Visiting Scientist at our own UC Irvine Keck AMS laboratory, which

*Corresponding author. Email: jsouthon@uci.edu 
allowed him to pursue his many radiocarbon interests without the burden of administrivia that goes with the positions of professor and laboratory director. We at Irvine thereby gained the benefit of his archaeological dating expertise, as well as a direct link to the earliest days of radiocarbon, which he was uniquely qualified to document (e.g., Taylor 2014).

Erv is best known for radiometric dating and for his many contributions to New World archaeology, but his interests were far wider than that simple characterization suggests. For example, his first major papers came about when he and Rainer Berger at UCLA were able to convince Libby that shell was in fact a suitable material for radiocarbon measurements (a major accomplishment in itself-see Libby 1955:44) and produced the first set of marine reservoir corrections for the West Coast of North, Central, and South America (Berger et al. 1966; Taylor and Berger 1967). His own laboratory used gas counting but he was an early collaborator with the University of Arizona AMS group in measurements on New World human remains (Taylor et al. 1985), and was at the forefront of support within University of California for establishment of an AMS facility at Lawrence Livermore National Laboratory in the 1980s. A nice example of the interdependence of the many fields impacted by radiocarbon is that his interest in anomalously old dates for bones associated with the destruction of Nineveh in $612 \mathrm{BC}$ (Taylor et al. 2010) led us to investigate in detail the structure of the ${ }^{14} \mathrm{C}$ calibration curve in this period, which in turn led to the discovery of a new Miyake event-a sharp increase in atmospheric $\Delta^{14} \mathrm{C}$ in $660 \mathrm{BC}$ (Park et al. 2017) that was likely driven by multiple solar Coronal Mass Ejection events. The growing availability of industrial diamonds and diamond-like films led him to speculate that the exceptional stability of the diamond lattice might reduce AMS ion source memory, and perhaps the use of a diamond-like material could eventually be the key to extending routine radiocarbon measurements beyond $60 \mathrm{kyr}$. Small pieces of gem diamond produced blanks equivalent to ages of up to $70 \mathrm{kyr}$ (Taylor and Southon 2007), a remarkable result from a small (0.5MV) AMS system, but with the unintended consequence that this paper is frequently cited in Creationist literature ("How can diamond be billions of years old if...?").

Nevertheless, a major part of Erv's legacy does indeed stem from his archaeological dating studies on humans in the New World. In the 1970s and ' $80 \mathrm{~s}$ he was an important contributor to ${ }^{14} \mathrm{C}$ studies which showed that several sets of bones previously considered to be tens of thousands of years old based on amino acid racemization dates were in fact midHolocene (Taylor et al. 1985). He also made significant contributions to bone sample preparation chemistry that included the use of chromatographically well-characterized amino acid extracts and studies of the non-collagenous protein osteocalcin (Taylor 1992). In 1996 he provided the first radiocarbon date for then recently discovered Kennewick skeleton which showed that the remains were from the early Holocene (Taylor et al. 1998). Unfortunately, this finding led to years of legal wrangling (in which Erv was not a participant), until permission was given for DNA studies which showed they were from an individual with clear genetic affinities with present day native Americans, and the remains were therefore repatriated and reburied.

Erv's work on the supposed Pleistocene remains in the western United States and his scrutiny of other early archaeological sites led some to characterize him as a diehard "Clovista" or Clovisfirster determined to debunk any possibility of a human presence in the New World prior to Clovis time, but this does a serious disservice to his character. Rather, he looked for the scientific rigor that he always tried to bring to his own studies, and as his work on the 
Chilean site of Monte Verde showed, he was happy to publish results that cleared up inconsistencies and supported the original assertion of antiquity (Taylor et al. 1999; George et al. 2003).

An aspect of his persona that may be unfamiliar to many in the radiocarbon community is that he was a practicing Christian and a strongly committed member of the Seventh-day Adventist Church, while as a scientist he was firmly convinced that the Biblical narrative of Creation in Genesis was allegorical rather than literal. His involvement in radiocarbon studies plus the diamond paper mentioned earlier brought him to the attention of members of the Young Earth movement who take the opposite view; and characteristically he never shied away from the ensuing arguments, but at least on his side they were always conducted in his usual courteous and thoughtful fashion. He put serious effort into explaining in detail how radiocarbon dating works, both to that group in particular and to the public in general; and one of his most recent publications in Radiocarbon (Taylor et al. 2017) was an exposition in layman's terms of the many ways that traces of radiocarbon could be measured in geologic materials that should contain no ${ }^{14} \mathrm{C}$.

He was a friend and a valued colleague to many of us and he is sorely missed.

\section{REFERENCES}

Berger R, Taylor RE, Libby WF. 1966. Radiocarbon content of marine shells from the California and Mexican west coast. Science 153:864-866.

George D, Southon J, Taylor RE. 2003. Resolving an anomalous radiocarbon determination on mastodon bone from Monte Verde, Chile. American Antiquity 70:766-772.

Libby W. 1955. Radiocarbon dating. 2nd edition. Chicago: Chicago University Press.

Park JH, Southon J, Fahrni S, Creasman PJ, Mewaldt R. 2017. Relationship between solar activity and $\Delta^{14} \mathrm{C}$ peaks in AD 775, AD 994, and $660 \mathrm{BC}$. Radiocarbon 59(4):1147-1156.

Taylor RE. 1992. Radiocarbon dating of bone: to collagen and beyond. In: Taylor RE, Long A, Kra RS, editors. Radiocarbon after four decades: an interdisciplinary perspective. New York: Springer-Verlag. p. 375-402.

Taylor RE. 2014. Passing of the last of the three who established ${ }^{14} \mathrm{C}$ dating: a historical note. Radiocarbon 56(3):913-921

Taylor RE, Berger R. 1967. Radiocarbon content of marine shells from the Pacific coasts of Central and South America. Science 158:1180-1182.

Taylor RE, Southon JR. 2007. Use of natural diamonds to monitor ${ }^{14} \mathrm{C}$ AMS instrument backgrounds. Nuclear Instruments and Methods in Physics Research Section B 259:282-287.

Taylor RE, Beaumont WC, Southon J, Stronach D, Pickworth D, 2010. Alternative explanations for anomalous ${ }^{14} \mathrm{C}$ ages on human skeletons associated with the 612 BCE destruction of Nineveh. Radiocarbon 52(2):372-382.

Taylor RE, Haynes CV Jr, Kirner DL, Southon JR. 1999. Radiocarbon analyses of modern organics at Monte Verde, Chile: no evidence for a local reservoir effect. American Antiquity 64: 455-460.

Taylor RE, Kirner DL, Southon JR, Chatters JC. 1998. Radiocarbon dates of Kennewick Man. Science 280:1171-1172.

Taylor RE, Payen LA, Prior CA, Slota PJ Jr, Gillespie R, Gowlett JAJ, Hedges REM, Jull AJT, Zabel TH, Donahue DJ, Berger R. 1985. Major revisions in the Pleistocene age assignments for North American human skeletons by $\mathrm{C}-14$ accelerator mass spectrometry: none older than 11,000 C-14 years B.P. American Antiquity 50:136-140.

Taylor RE, Southon JR, Santos GM. 2017. Misunderstandings concerning the significance of AMS background ${ }^{14} \mathrm{C}$ measurements. Radiocarbon 60(3):727-749. 